Ambiente \& Água - An Interdisciplinary Journal of Applied Science
ISSN 1980-993X - doi:10.4136/1980-993X
www.ambi-agua.net
E-mail: ambi.agua@gmail.com

\title{
Sediments of watersheds from Frutal and Bebedouro Streams (Frutal, MG, Brazil) as an indicator of human activities
}

\author{
doi:10.4136/ambi-agua.1978
}

Received: 01 Aug. 2016; Accepted: 18 Oct. 2016

\author{
Sofia Luiza Brito ${ }^{*}$; Thiago Torres Costa Pereira ${ }^{2}$; Inez Cristina Martins ${ }^{2}$ \\ ${ }^{1}$ Fundação Centro Internacional para Educação, Capacitação e Pesquisa Aplicadas em Águas \\ (UNESCO-HidroEX), Frutal, MG, Brasil \\ Diretoria de Pesquisa \\ ${ }^{2}$ Universidade do Estado de Minas Gerais (UEMG), Frutal, MG, Brasil \\ Departamento de Ciências Exatas e da Terra \\ *Autor correspondente: e-mail: sofialuizabrito@gmail.com, \\ thiago.solos@gmail.com,inezcmartins@gmail.com
}

\begin{abstract}
Soil degradation is a physical process intensified by political and socioeconomic factors, and by the population growth of the $20^{\text {th }}$ century. In this study, we evaluated the sediments of the Frutal and Bebedouro Streams, located in Frutal municipality, Minas Gerais State, Brazil, and their relation to major human activities that are responsible soil erosion and silting. Samples were collected between 2012 and 2013 for the determination of granulometric composition, organic matter content, and minerals in sediments. The Wentworth scale was used for particle size measurement, and then the size classes regrouped to ABNT scale (NBR 6502/1995). The results found that agriculture and cattle ranching are the main activities that cause intense erosion and silting in both watersheds. Bebedouro Stream is better preserved, as it is completely located in rural area with larger riparian vegetation, unlike the mid-stretch of Frutal Stream, which is located in an urban area. Quartz is the predominant mineral in the sediments as the soils of the region are formed by sandstones; consequently, few nutritional elements were found in the studied samples. Principal component analysis showed that water quality parameters are correlated to silt/clays and organic matter content in most of the collected stations.
\end{abstract}

Keywords: cerrado, rhodic ferralsols, soil erosion.

\section{Sedimentos das microbacias do Ribeirão Frutal e Córrego Bebedouro (Frutal, MG) como indicador da ação antrópica}

\section{RESUMO}

A degradação do solo é um processo físico intensificado por fatores políticos e socioeconômicos, acentuado drasticamente pelo crescimento da população no século $\mathrm{XX}$. $\mathrm{O}$ objetivo deste estudo foi avaliar os sedimentos do Ribeirão Frutal e Córrego Bebedouro, localizados no município de Frutal, Minas Gerais, Brasil, e sua relação com as principais atividades humanas que são responsáveis pelo processo avançado de erosão do solo e assoreamento. Foram coletadas amostras entre 2012 e 2013 para determinar a composição granulométrica, teor de matéria orgânica e sais minerais encontrados nos sedimentos. Para a 
medição do tamanho das partículas, foi utilizada a escala de Wentworth e, posteriormente, as classes de tamanho foram reagrupadas para a escala ABNT (NBR 6502/1995). De acordo com os resultados, a agricultura e a pecuária são as principais atividades que causam erosão acelerada e assoreamento em ambas as bacias hidrográficas. O Córrego Bebedouro é melhor preservado, uma vez que se encontra totalmente inserido na área rural, com mata ciliar melhor preservada do que o trecho médio do Ribeirão Frutal, localizado na área urbana. O quartzo é o mineral predominante nos sedimentos devido ao solos da região serem formados por arenitos, consequentemente, com poucos elementos nutricionais. A análise de componentes principais mostrou que parâmetros de qualidade da água estão correlacionados com a fração silte/argila e matéria orgânica na maioria das estações.

Palavras-chave: cerrado, erosão do solo, latossolo vermelho.

\section{INTRODUCTION}

Soil degradation is a physical process intensified by political and socioeconomic factors and has been accentuated drastically by $20^{\text {th }}$ century population growth (Lal, 2001). In watersheds with natural forest cover, vegetation protects against soil erosion, silting, and excessive nutrient leaching, the riparian zone is a very important area to help maintain the water supply's quantity and quality (Morgan, 2005). On the other hand, practices that follow after removal of the original vegetation tend to produce intense and prolonged degradation of water quality (Klink and Machado, 2005).

Sediments are an important compartment of the aquatic environment, and result from interacting processes that occur in a water catchment. For this reason, they are an essential tool for the study of the manner and intensity of impacts to which surrounding terrestrial ecosystems are or have been subjected (Esteves, 2011).

Currently, there are several impacts in the natural environments, particularly in the Brazilian Tropical Savanna (Cerrado), resulting from the Green Revolution that has occurred in Brazil since the 1960s. In this case, the agricultural intervention in the soils of the Frutal region (MG) is marked in many cases by inadequate management, which accelerates erosion, and often results environmental degradation that is difficult to reverse.

The use of modern agricultural technology and intensive use of the soil beyond its carrying capacity has been shown to be key factor in increasing erosion and expansion of degraded Cerrado areas. It may be a future risk to food production and security, particularly for low-income farmers. Thus, the intensive use of mechanization, fertilizers and pesticides compromises the pedological cover, the watersheds and the agricultural ecosystems themselves.

According to Cunha et al. (2008), the main threat to biodiversity in the Cerrado is the expanding of agricultural frontier, which has been made by loss of original vegetation converted to croplands and pasture. This expansion of agriculture has occurred with intensive use of pesticides and fertilizers, uncontrolled irrigation, compaction of soil by cattle ranching, extensive monoculture (traffic of heavy vehicles) and increasing of landholdings.

Former studies in Frutal and Bebedouro watersheds showed degradation of environment by removal of riparian vegetation, high erosive rates, silting and organic material present in the riverbeds of two streams (Ferreira, 2005; Souza, 2009). Both watersheds present laminar erosion and soil depletion under pasture, increased by runoff from rural roads. There are also records of erosion in rills: three large gullies in the Frutal watershed, the largest of them occupying an area of approximately 15 ha (Cardoso, 2008).

Factors such as drainage and soil structure, associated with a flat relief and the presence of several streams, are the main conditions for intensive agricultural use in the Frutal region. Despite the importance of soils to the Cerrado's survival, little attention has been given to 
their use and conservation since the area was first occupied. Soil conservation begins with vegetation maintenance, to minimize the impact of droplets during rainfall and thus reduce the formation of rills in the soil, consequently reducing erosion (Morgan, 2005).

The aim of this study was to evaluate the sediments of the Frutal and Bebedouro Streams, located in Frutal municipality, Minas Gerais State, Brazil, and their relation to major human activities that are responsible for advancing the process of soil erosion, silting and water quality degradation.

\section{MATERIALS AND METHODS}

\subsection{Study Area}

Frutal municipality is located in meso-region of Triângulo Mineiro, Minas Gerais State, with an economy based mainly upon agricultural activity, especially sugar cane $(65 \%)$ and cattle ranching, with about 190,000 heads (IBGE, 2014). Cattle usually have access to rivers for watering, and their excessive trampling was widely diagnosed as being the cause of some erosive processes that occur in the study area.

The watersheds of Frutal (S 19 $55.941^{\prime}$ W $48^{\circ} 55.427,124.2 \mathrm{~km}^{2}$ ) and Bebedouro Streams (S 1957.064' W 48 $57.775^{\prime}, 165.0$ km²), belong to the Grande River Basin (MG/SP States), flowing into the Marimbondo Reservoir (Furnas Company S/A). Since 1976, the water supply for the municipalities have come from the Frutal Stream (Varanda, 2007), where the urban area and road BR-364 already reach the watershed, upstream of the water catchment. Downstream of the urban area effluents from the sewage treatment plant discharge into Frutal Stream.

The Frutal region has tropical weather, with a well-defined dry season. Annual mean precipitation varies between 1,400 and $1,500 \mathrm{~mm}$, with rains concentrated in the period between October and March. The relief comprises the Plateau of Paraná Sedimentary Basin. It is an extension, in Minas Gerais, of formations that occupy large areas in São Paulo, Paraná, Santa Catarina and Rio Grande do Sul States, and corresponds to the sedimentary layers on basaltic lava flows. The stratigraphic sequence in Frutal is marked by basalts of the Serra Geral Formation ( \pm 120 million years ago) over which occur sandstones of the Vale do Rio do Peixe Formation $( \pm 80$ million years ago) and sandstones and conglomerates of the Marília Formation ( \pm 70 million years ago) (CPRM and SGMB, 2003).

Beneath the Cerrado vegetation, Dystric Rhodic Ferralsols (Typical) of medium texture predominate in the watersheds. They are deep soils, well-drained and with high aluminum content. Currently, these soils are widely used to cultivate sugar cane, corn, sorghum, soybeans, irrigated pineapple crops, grazing, rubber tree, and others annual crops.

Soil classes like Haplic Cambisols, Haplic Lixisols and Arenosols also occur. Systems of Tropical Wet Savanna (Veredas) occur in hydromorphic environments.

\subsection{Proceedings}

Samplings were taken in dry (September/2012) and rainy seasons (March/2013). A third sampling (August/2013) was taken for X-ray mineralogical analyses. Sediment samples were collected at 28 stations: 19 in Frutal Stream, 8 in Bebedouro Stream, and 1 at Station J - the union of the streams (Figure 1). In Frutal Stream, more sampling stations were used because its watershed has more tributaries, which provide the city's water supply and suffer severe impacts of the adjacent urban area and road BR-364. To assess possible effects of the tributaries, the samples were taken as close as possible to the mouths of the tributaries. In Frutal Stream, the tributaries are represented by Stations F2, F7, F9, F11, F17, while in the Bebedouro Stream, with only two tributaries are the B4 and B7 Stations.

Sampling Stations R1 (degraded headwater) and R2 (preserved headwater) were named 
separately for hydrodynamic studies, but they were considered altogether for sediment studies. Vertente Grande Stream (stations F14 to F17) deserves attention because it is responsible for the drainage of the urban area. In Bebedouro Stream, Station B7 is the most impacted, without riparian vegetation. Stations J, B8 and F13 are located in a flooded area of Marimbondo reservoir.

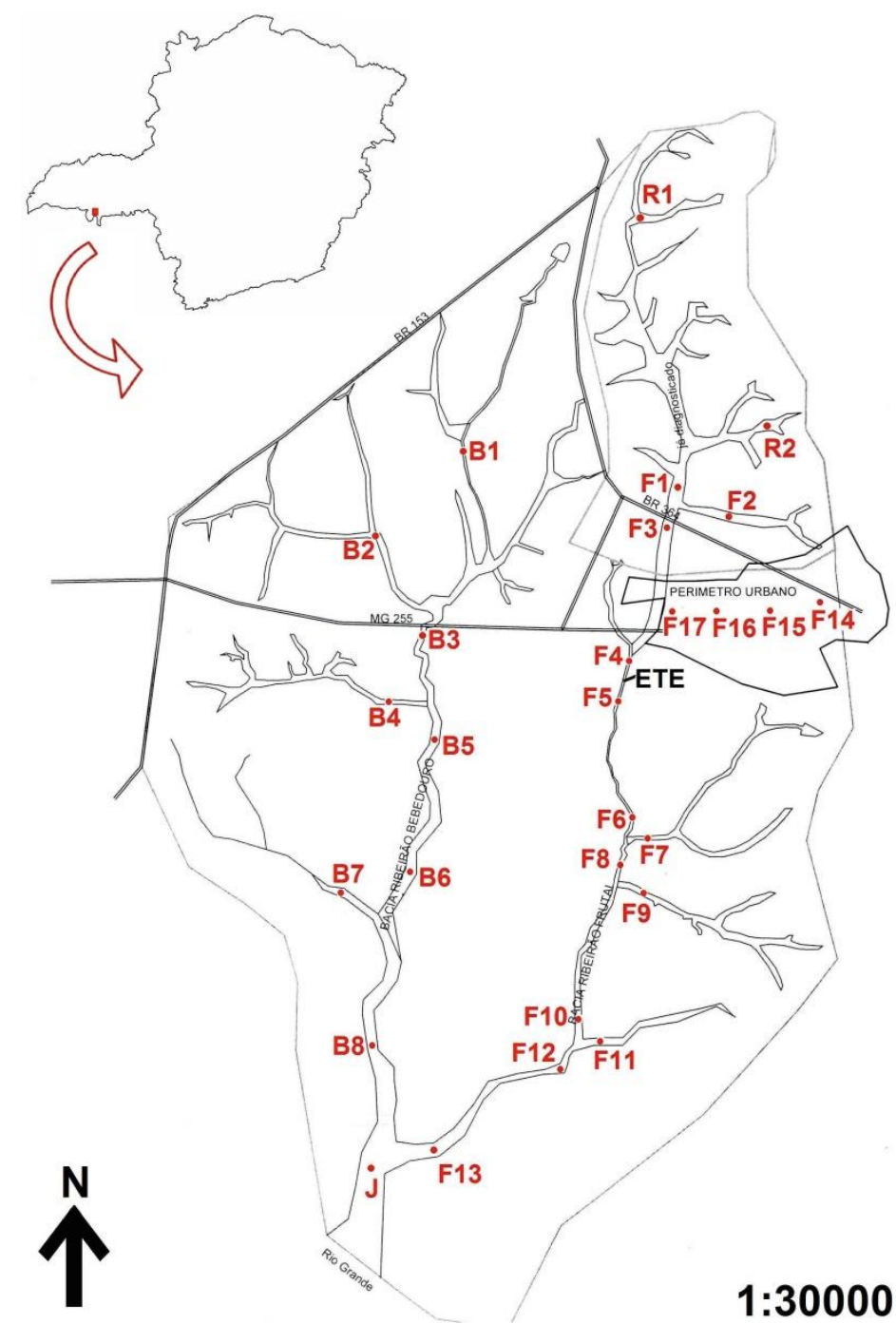

Figure 1. Station samplings in watersheds of Frutal and Bebedouro Streams, Frutal municipality, Minas Gerais State, Brazil. F: stations at Frutal watershed; B: stations at Bebedouro watershed; R1: degraded headwater; R2: preserved headwater; ETE: sewage treatment plant of Frutal city. Source: modified from Menezes (2011).

All stations also measured water temperature, $\mathrm{pH}$, electrical conductivity, dissolved oxygen concentration, total dissolved solids, turbidity with a Hanna HI9828 multi-analyzer. Water samples were collected to determine total alkalinity, chlorophyll-a, total phosphorus and total nitrogen, and were analyzed in laboratory according to the Standard Methods of Water and Wastewater (APHA et al., 2012).

As the water column was shallow, sediment samples were collected by means of a manual sampler corer, Kajac type. Samples were stored in plastic bags and refrigerated until analysis to preserve their organic matter content. According to Santos et al. (2013), all particulated mineral materials were considered for granulometric composition: individual 
mineral grains, rock fragments not modified or partially modified, concretions, nodules, and similar materials cemented.

Sediment samples from each station ( $c a .100 \mathrm{~g}$ ) were dried at $40^{\circ} \mathrm{C}$ for 48 hours (Almeida et al., 2012). Dry material was smoothly macerated in a mortar to break down the aggregates contained in the sediment. The samples were then sieved through a sieve shaker for 30 minutes. The resulting fractions in each sieve were weighed to calculate the percentage. The grain classification followed the Wentworth Scale (Table 1), as proposed by Suguio (1973). For graphs and statistical analyses, the size classes were regrouped according to the ABNT scale (ABNT, 1995), considering three classes: silt/clay $(<0.06 \mathrm{~mm})$, sand $(0.06 \mathrm{a}$ $2.00 \mathrm{~mm})$ and gravel/pebble $(>2.0-60<\mathrm{mm})$.

For organic matter content, sediment samples were dried at $60^{\circ} \mathrm{C}$ for 24 hours, and after that weighed to obtain weight 1 (total dry weight). The samples were then calcinated in a muffle at $460^{\circ} \mathrm{C}$ for 2 hours to obtain weight 2 (inorganic matter). Organic matter content was calculated by the difference between weights 1 and 2, according to Bicudo and Bicudo (2004).

Table 1. Sieve size, Wentworth scale for granulometric composition and correspondence to NBR 6502 (ABNT, 1995).

\begin{tabular}{cclc}
\hline Sieve size $(\mathrm{mm})$ & Phi scale & Classification & NBR 6502/1995 \\
\hline 2 & -1 & Very coarse sand & Sand \\
1 & 0 & Coarse sand & \\
0.5 & 1 & Medium sand & \\
0.25 & 2 & Fine sand & \\
0.125 & 3 & Very fine sand & \\
0.063 & 4 & Silt & Silt/Clay \\
\hline
\end{tabular}

The minerals present in sediments were identified by X-ray diffraction (XRD), and nine representative stations were selected: R1, R2, F3, F12, F13 (Frutal Watershed), and B1, B5, B6, B7 (Bebedouro Watershed). A diffractometer (PANalytical / X`Pert Pro) was used, with $\mathrm{CoK} \alpha$ radiation in the range between 4 and $50^{\circ} 2 \theta$, at intervals from $0.017^{\circ} 2 \theta$ to $1 \mathrm{step} \mathrm{s}^{-1}$, at a $40 \mathrm{kV}$ voltage and $30 \mathrm{~mA}$ current. The interpretation of XRD data was based on Bish and Post (1989).

Differences between watersheds and seasons for sediment samples were tested by analysis of variance (ANOVA). To assess the impact of silting of the two watersheds on the quality of water, a principal component analysis (PCA) was performed considering the fractions of sieves and physical and chemical parameters. Variables with a low range of variation or redundancy in the data were not employed in the PCA.

\section{RESULTS AND DISCUSSION}

During the sampling, the first visual observation in the field reveals that both watersheds have several points of soil loss associated with various uses, especially intensive agriculture (sugar cane) and extensive cattle ranching, culminating in accelerated erosion (laminar mainly) and silting of stream channels.

Mean water temperatures were $26.2^{\circ} \mathrm{C}$ and $27.1^{\circ} \mathrm{C}$, between the dry and rainy seasons, respectively. These data prove that the seasonality of the region is characterized by rainfall, not by temperature range (summer/winter). The $\mathrm{pH}$ values were near neutrality varying between 6.42 and 7.43. Electrical conductivity values exceeded the water quality standard 
$\left(100 \mu \mathrm{S} \mathrm{cm}^{-1}\right)$ in stations at Frutal Stream that suffer direct impacts of farming (R1), of the sewage treatment plant (F5, F6, F8, F10, F12) and of the urban area (F15, F16, F17). In these stations, dissolved oxygen concentrations were under the water quality standard of $5 \mathrm{mg} \mathrm{L}^{-1}$ (CONAMA, 2005).

Mean values of total dissolved solids were higher during the rainy season $\left(54.2 \mathrm{mg} \mathrm{L}^{-1}\right)$ due to the higher loading of flash floods in relation to the dry season $\left(48.1 \mathrm{mg} \mathrm{L}^{-1}\right)$. Higher values of turbidity (30.13 NTU) and total alkalinity $\left(130.1 \mathrm{mg} \mathrm{L}^{-1} \mathrm{CaCO}_{3}\right)$ were observed in stations impacted by the sewage treatment plant (F5 and F6), but did not exceed the water quality standard of $100 \mathrm{NTU}$ and $500 \mathrm{mg} \mathrm{L}^{-1} \mathrm{CaCO}_{3}$, respectively. Contrasting, chlorophyll- $a$, total phosphorus and nitrogen standards of $30 \mu \mathrm{g} \mathrm{L}^{-1} ; 0.100 \mathrm{mg} \mathrm{L}^{-1}$ and $2.18 \mathrm{mg} \mathrm{L}^{-1}$ (CONAMA, 2005) were exceeded at these two stations. Higher values were observed on Station F5 in the dry season, when chlorophyll- $a$ reached $124.3 \mu \mathrm{g} \mathrm{L}^{-1}$, total phosphorus: $0.116 \mathrm{mg} \mathrm{L}^{-1}$ and total nitrogen: $6.46 \mathrm{mg} \mathrm{L}^{-1}$. Total nitrogen standards also were exceeded in Stations F6 (5.68 $\left.\mathrm{mg} \mathrm{L}^{-1}\right), \mathrm{F} 15\left(2.63 \mathrm{mg} \mathrm{L}^{-1}\right)$ and F16 (4.24 $\left.\mathrm{mg} \mathrm{L}^{-1}\right)$ in the same season.

Granulometric composition of samples collected in Frutal Stream (Figure 2) showed the predominant fractions in sediments are related to sieves $2,0.25$ and $0.125 \mathrm{~mm}$ (very coarse sand, fine sand and very fine sand, respectively). The high amount observed in the mesh of 2 $\mathrm{mm}$ is probably overestimated for the formation of stable aggregates in the soil, with difficult dispersion, while smaller meshes, as described above, confirm the higher concentration of sand in the surrounding soils, especially Rhodic Ferralsols (FR), which produced sediments that reflect its texture (mean) and morphological conditions observed at field. Comparing the dry and rainy seasons, no significant difference was observed $(F=1.644 ; p=0.208)$.

Regrouping the fractions in three classes (Figure 2), in general, an increase in the proportion of sand $(0.05$ to $2.00 \mathrm{~mm})$ was observed in the rainy season, in contrast to very fine particles (silt/clay) or very coarse particles (gravels/pebbles). In most of the stations and seasons, the sand fraction represented more than $50 \%$ of sediments, reaching $99.6 \%$.

As an exception, the fraction gravel/pebble showed its higher percentages at Stations F14 (68.3\%) and F16 (52.10\%) in the dry season, and at Stations F15 (67.1\%) and F7 (61.6\%) in the rainy season. These stations belonging to the Vertente Grande Stream (completely located in the urban area) and the Marianinho Stream (Station F7, a tributary of the Frutal Stream), which are impacted by the disposal of waste construction. The fraction silt/clay showed higher percentages only in Stations F5 (35.5\%) and F6 (24.4\%), downstream to effluent discharges from sewage treatment plant.

Granulometric fractions of Bebedouro Stream are presented in Figure 3, which shows the same pattern of concentration of grains as samples in Frutal Stream. The high amount of grains retained in sieves of 2, 0.25 and $0.125 \mathrm{~mm}$, especially in last two meshes, indicates the texture and morphology of Rhodic Ferralsols FR predominating in the region, originated from clastic sedimentary rocks.

Regrouping the fractions of different sieves of sediments from Bebedouro Stream into three classes, the same pattern was observed as of Frutal Stream with a predominance of sand $(0.05$ a $2.00 \mathrm{~mm})$. There is a slight increase of finest fractions (silt/clay), during rainy season, in stations downstream, especially in B8 (7.9\%) and $\mathrm{J}(12.2 \%)$, due to higher turbidity and very fine suspended particles, that naturally happens in precipitation periods. However, Figure 3 shows a static structure of textural distribution, without significant difference between seasons $(\mathrm{F}=0.597 ; \mathrm{p}=0.453)$ when compared to Figure 2. The fraction gravel/pebble was predominant only at Station B2 in the dry $(53.9 \%)$ and rainy seasons (59.1\%); this is a headwater stretch, slightly impacted and with preserved riparian vegetation. Comparing both watersheds, there was no significant difference between sediment fractions $(\mathrm{F}=2.566 ; \mathrm{p}=0.115)$. 


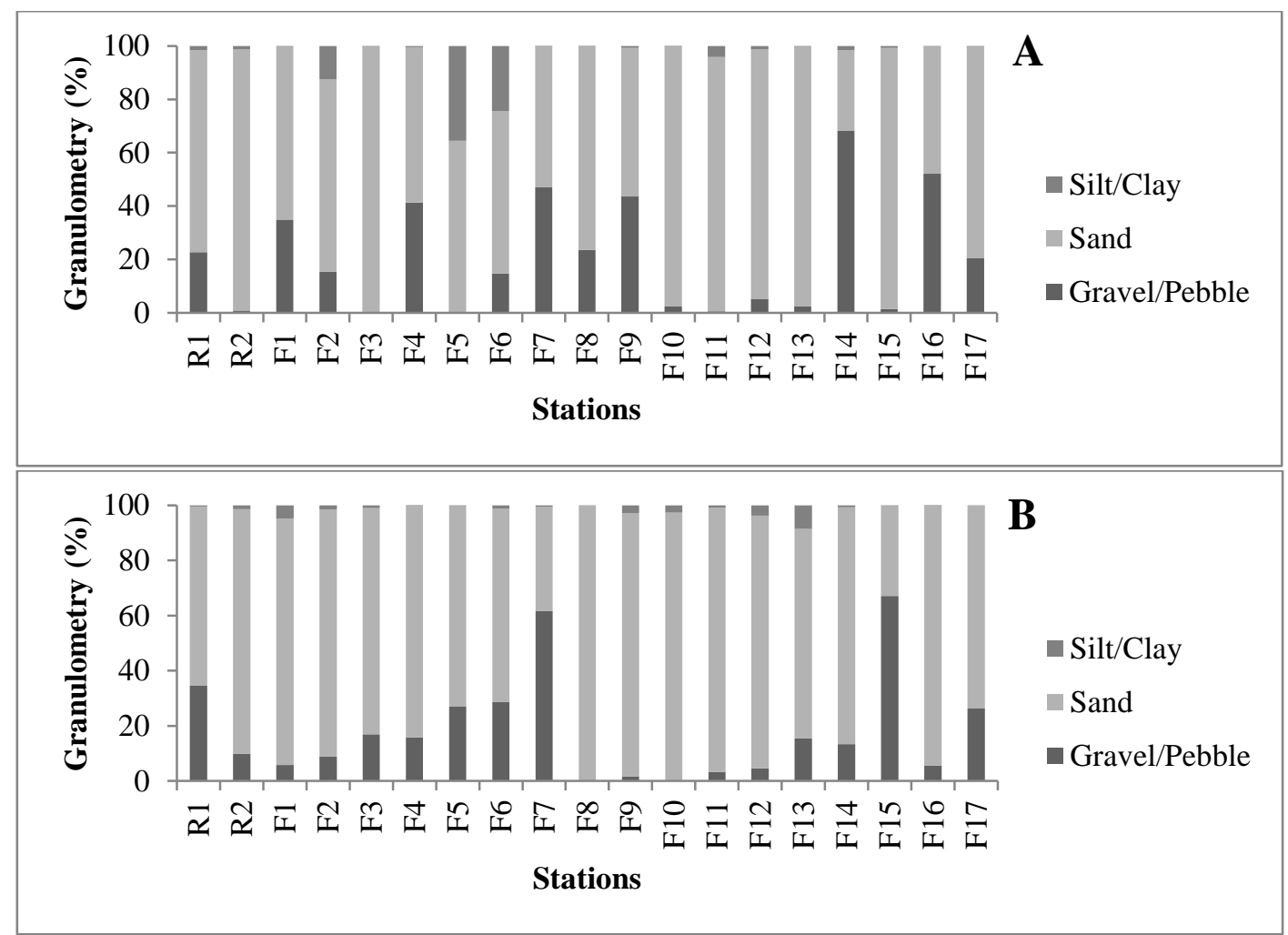

Figure 2. Granulometric composition of Frutal Stream in the dry season - A (Set/2012), and the rainy season - B (Mar/2013), according to ABNT scale (ABNT, 1995).

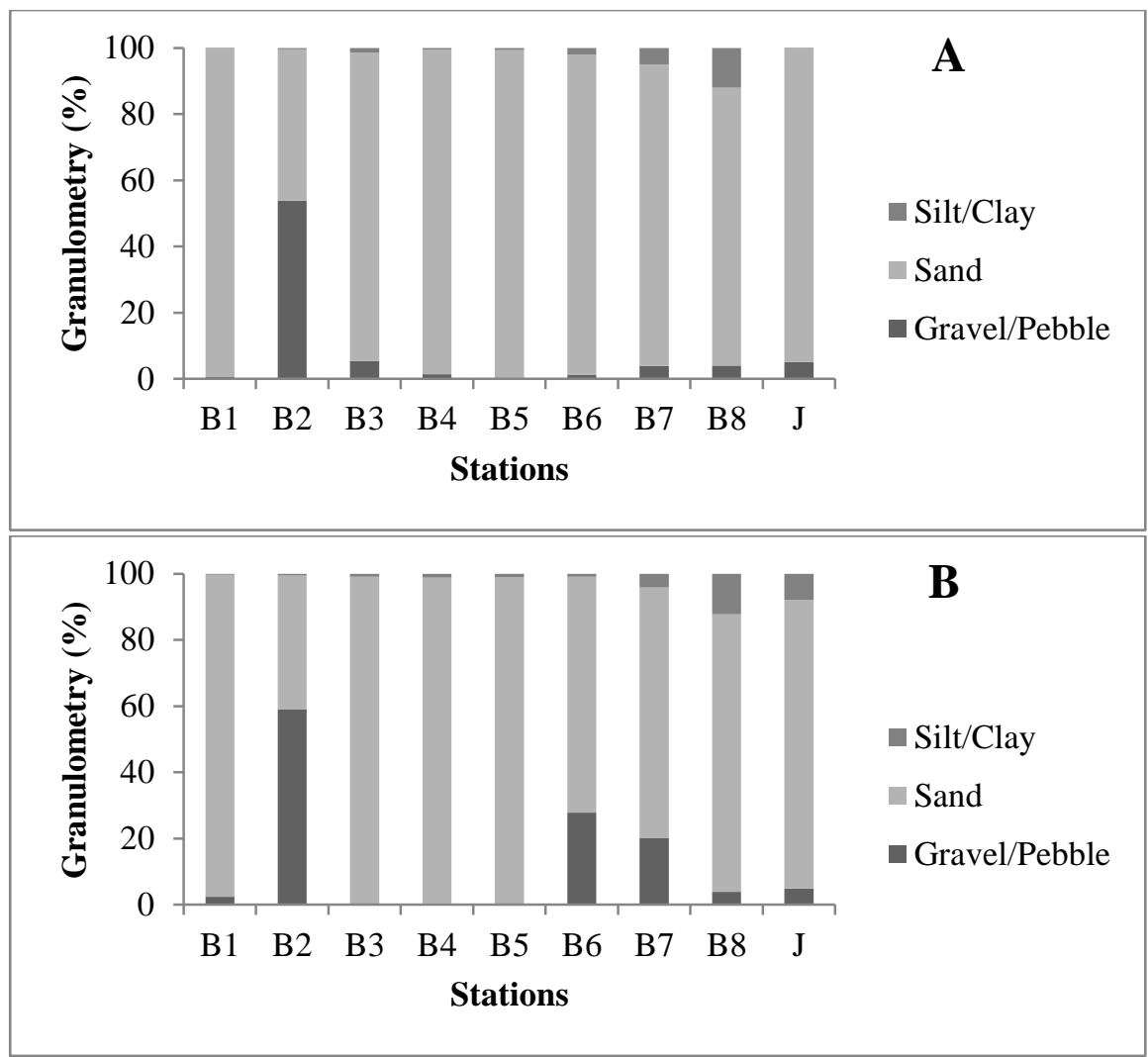

Figure 3. Granulometric composition of Bebedouro Stream in the dry season - A (Set/2012), and the rainy season - B (Mar/2013), according to ABNT scale (ABNT, 1995). 
Percentages of organic matter content are shown in Figure 4. As expected, there was a predominance of inorganic material, associated with the higher amount of sand in the samples. As expected for upstream stretches, Station R1 had higher fractions of gravel/pebble; but because it is a degraded headwater, the erosive processes are reflected in the low organic matter content. On the other hand, Station R2, being a headwater with preserved riparian vegetation, shows higher values of organic matter due to the contribution of allochthonous litter.

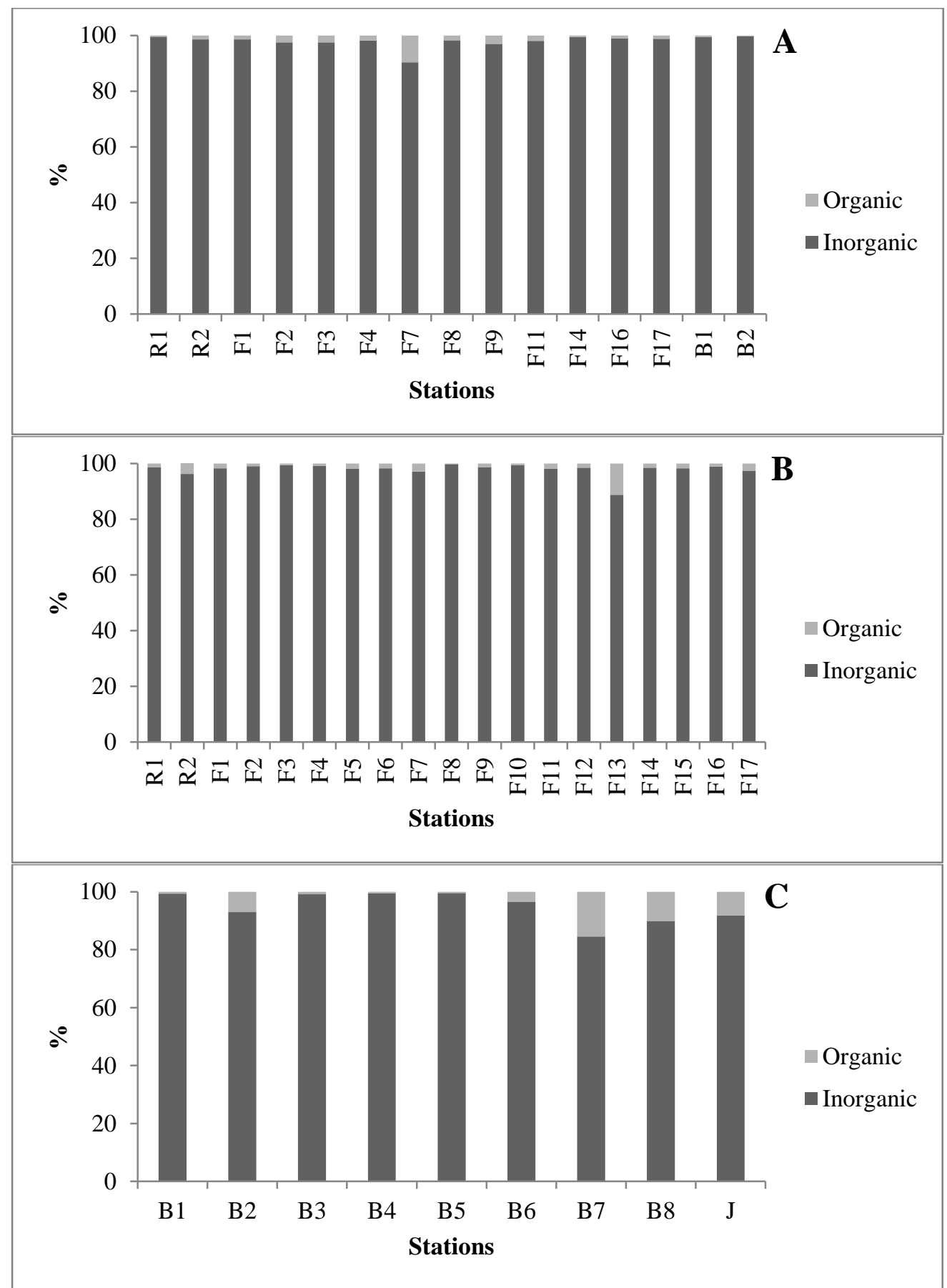

Figure 4. Organic matter content of Frutal and Bebedouro Streams in the dry season - A (Set/2012), and the rainy season - B and C (Mar/2013). In A, the presentation of only a few stations of both watersheds is due to loss of samples. 
XRD results of sediments from Frutal and Bebedouro Stream are found in Figures 5 and 6. In most stations only quartz was observed as a mineral component.
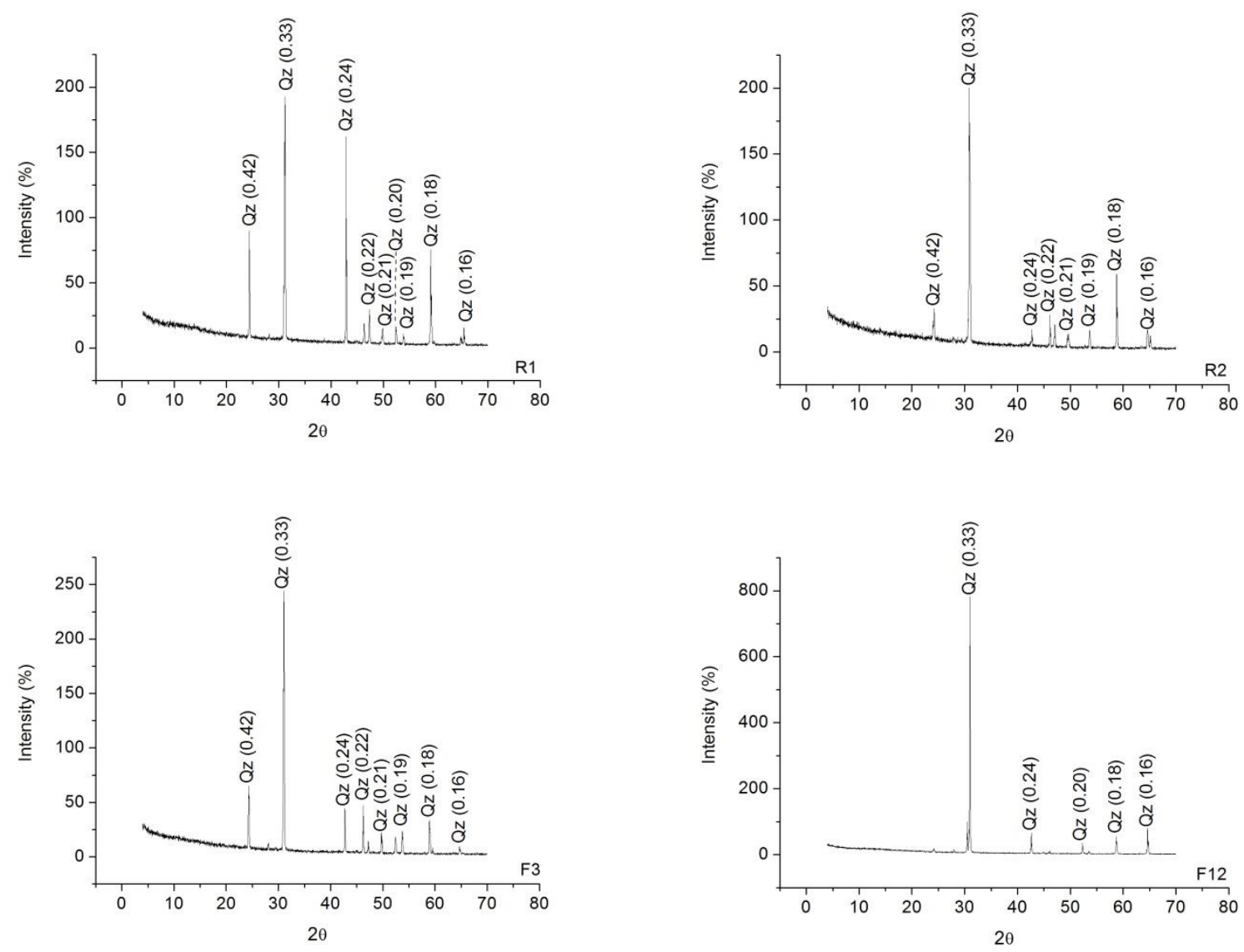

Figure 5. XRD results of stations R1, R2, F3, F12 - Frutal Stream. Spacing “d” in nm. Qz - quartz.

For stations $\mathrm{F} 13$ and $\mathrm{B} 7$, clay minerals kaolinite $\left(\mathrm{Al}_{2} \mathrm{Si}_{2} \mathrm{O}_{5}\left(\mathrm{OH}_{4}\right)\right)$, gibbsite $\left(\mathrm{Al}_{2} \mathrm{O}_{3}\right)$, anatase $\left(\mathrm{TiO}_{2}\right)$ and hematite $\left(\mathrm{Fe}_{2} \mathrm{O}_{3}\right)$ (Figure 7) were found in the sediments observed. Station $\mathrm{F} 13$, because it is further downstream, receives all the sediment loads of the watershed of Frutal Stream. This explains the detection of oxides, which are clay minerals, which may be free or forming stable micro-aggregates.

Figure 2-B shows a certain proportion of silt/clay in rainy season, whose minerals were consequently detected in X-ray diffraction. At Station B7, clay minerals were also detected in the sediments. This station is located in a further tributary of Bebedouro Stream, highly silted due to the complete removal of its riparian vegetation, which also brought sediments, subsequently collected and analyzed by XRD.

Principal component analysis (Table 2, Figure 8) showed in first factor (45.9\%) a strong correlation among silt/clay fractions and physical and chemical water quality parameters: electrical conductivity, total dissolved solids, total alkalinity, chlorophyll- $a$ and total phosphorus and nitrogen. In the second factor (18.3\%), the separation between stations where predominate sand and those ones with the presence of gravel/pebble was clear. The total percentage of explanation is $64.2 \%$. In Figure 8, it is also possible to verify a weak but significant correlation (coefficient below 0.70) between altitude and gravel/pebble; this fraction was higher in some stations upstream on both watersheds (especially R1 and B2). 

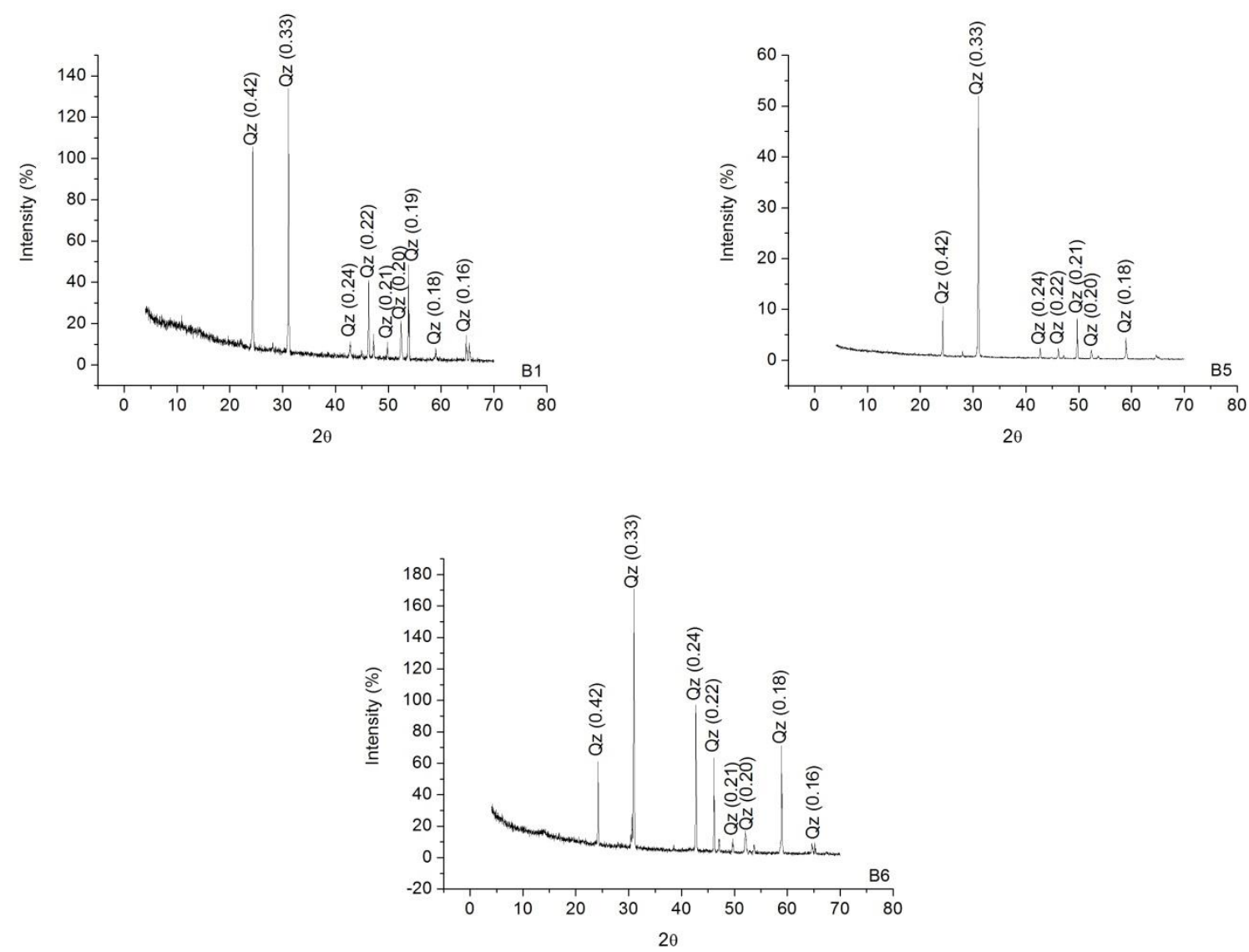

Figure 6. XRD results of stations B1, B5, B6 - Bebedouro Stream. Spacing “d” in nm. Qz - quartz.
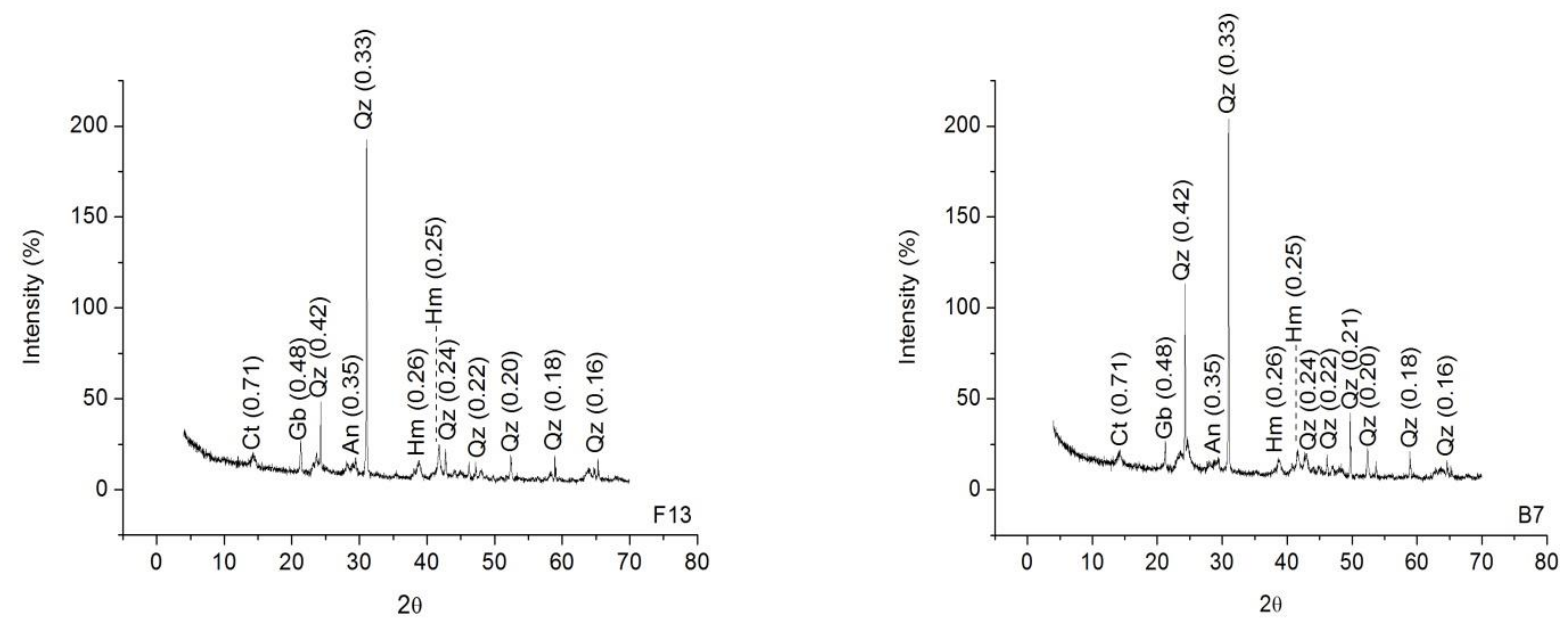

Figure 7. XRD results of Station F13 (left) and B7 (right) - Frutal Stream. Spacing "d" in nm. Qz: quartz, Ct: kaolinite, Gb: gibbsite, An: anatase, Hm: hematite. 
Table 2. Principal component analysis for granulometric composition of sediments and physical and chemical water parameters of Frutal and Bebedouro Streams (Frutal, MG). Values in bold represent significant correlations with factors $(\mathrm{p}<0.05)$.

\begin{tabular}{lll}
\hline Variable & Factor 1 & Factor 2 \\
\hline Gravel/Pebble & 0.0542 & $\mathbf{- 0 . 8 9 6 3}$ \\
Sand & 0.1948 & $\mathbf{0 . 8 6 1 2}$ \\
Silt/Clay & $\mathbf{- 0 . 7 8 8 3}$ & 0.1445 \\
Altitude & 0.1446 & $\mathbf{- 0 . 6 3 3 7}$ \\
Dissolved Oxygen & 0.6411 & -0.0276 \\
Electrical Conductivity & $\mathbf{- 0 . 8 4 1 1}$ & -0.1092 \\
Total Dissolved Solids & $\mathbf{- 0 . 8 1 6 6}$ & -0.1083 \\
Temperature & -0.3286 & 0.5667 \\
Turbidity & -0.6668 & 0.1442 \\
Total Alkalinity & $\mathbf{- 0 . 8 2 1 0}$ & -0.1843 \\
Chlorophyll- $a$ & $\mathbf{- 0 . 8 0 5 5}$ & 0.0274 \\
Total Phosphorus & $\mathbf{- 0 . 9 6 4 9}$ & 0.0052 \\
Total Nitrogen & $\mathbf{- 0 . 8 3 1 5}$ & -0.0986 \\
\hline
\end{tabular}

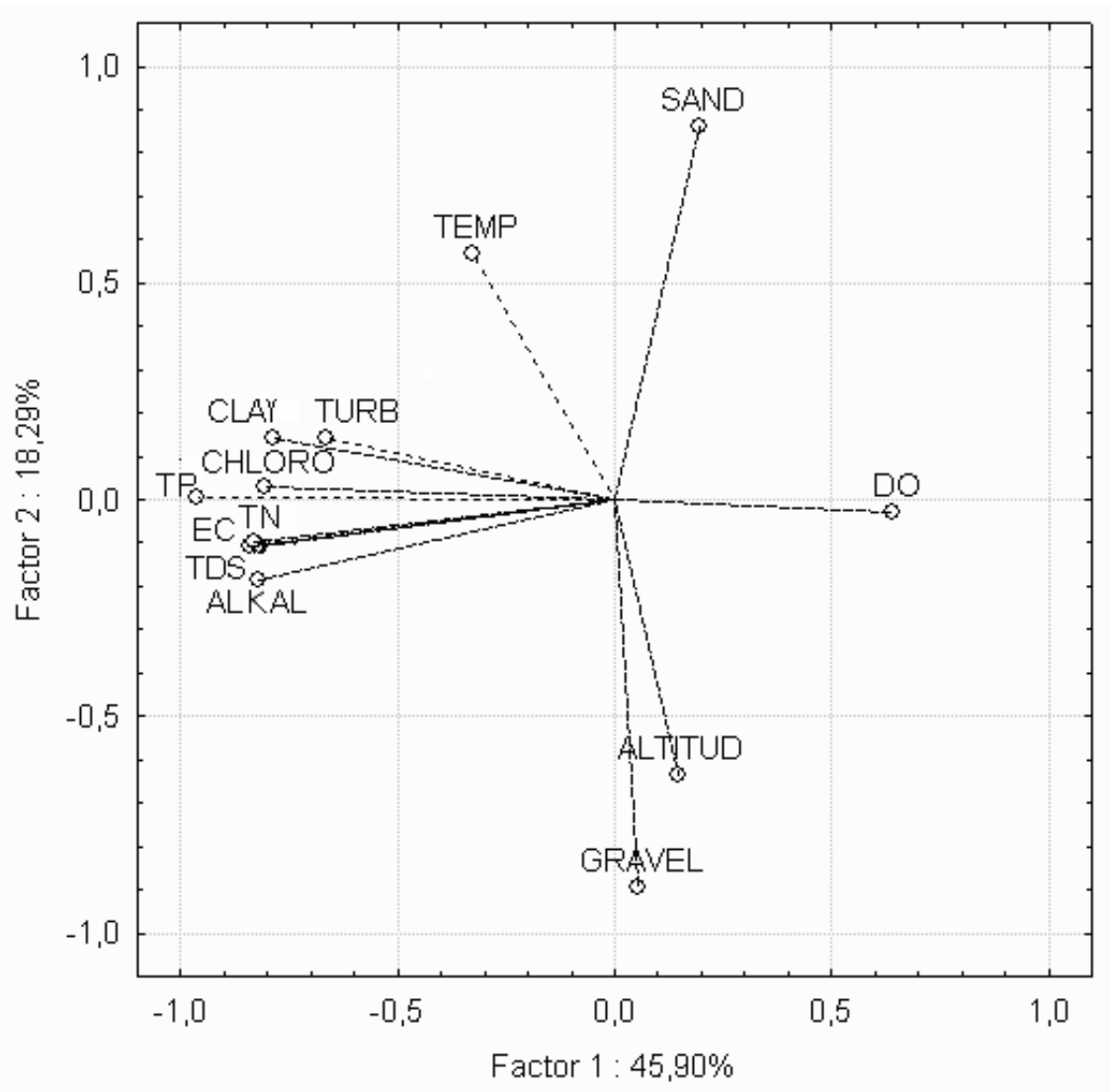

Figure 8. Principal component analysis for granulometric composition of sediments and physical and chemical water parameters of Frutal and Bebedouro Streams (Frutal, MG). 
The increasing in the sand fraction during the rainy period, even while not significant, evidences the process of leaching to which both watersheds are submitted. Quartz is the predominant mineral in sediments due to the fact that the soils of the region are formed (broadly) from sandstone, and because they are highly weathered; basically this primary mineral in the coarse fraction of soil (or on this study case, sediment) remained. Within the sequence weathering, this mineral is the most resistant to chemical change in environmental systems. At the same time, it reveals little nutritional reserves of the sediments studied. The clays detected could be from the processing of minerals from both the Vale do Rio do Peixe Formation (environmental dominance) and basalts of the Serra Geral Formation.

According to Kämpf et al. (2012), the mineralogy of Ferralsols predicts the occurrence of kaolinite, iron and aluminum oxides, with minor proportions of other components in the clay fraction. The possibility of occurrence, at some points, of outcrop/weathering basalts of the Serra Geral Formation, which is stratigraphically below the sandstones of the Vale do Rio do Peixe Formation, contributes to the occurrence of clay minerals that appeared in X-ray diffractograms.

It is remarkable that the highest proportion fraction $>2 \mathrm{~mm}$ found in the Frutal watershed (especially in the Vertente Grande Stream) is associated with increased of anthropogenic changes and the production of rubble. That is, the supply of gravel/pebble diagnosed is not only due to the mineral fragments and rocks of the region. Bebedouro Stream, comparatively, is in better conservation status once completely inserted in the rural area, with larger riparian vegetation on its margins and without urbanization as in Frutal watershed.

There are more than 100 meters of difference between the headwaters of the Frutal Stream and its confluence into the Grande River. The higher inclination, located especially in upstream stretch, characterizes the watershed as ecologically fragile, where runoff, coupled with intensive agriculture, has higher potential energy that disaggregates the exposed soil and transports sediments to adjacent water bodies (Merten and Minella, 2002).

An important fact should be noted in Stations B3, B4, B5 and B6 in the Bebedouro Stream and F10 in the Frutal Stream. At these stations, there are basaltic outcrops, forming rapid stretches, providing oxygenation of the water and improvement in its quality. For this reason, they should be analyzed with reservations, as the sand predominance does not reflect the true conditions of these stations, which also show well-preserved riparian vegetation, being also tourist attractions in the region.

The transport and deposition of sediments occur continuously in the studied watersheds, consequently influencing the operation of water systems. Pesticides can be transported by being adsorbed into inorganic or organic particles in the sediments. In this way, studies of sedimentation are very relevant currently, informing the strategic planning of budgets for the rational management of soil and water (Merten and Minella, 2002).

Silted material is one of the main transporters of nutrients and pollutants, contributing to the eutrophication/contamination of aquatic environments (Santos, 2002). Among the inorganic components, clays have a significant ion exchange capacity and transport chemical compounds adsorbed in them (Payne, 2006). This relationship was evidenced by principal component analysis, where water quality variables showed higher values correlated to the presence of the fraction silt/clay and/or organic matter content in the sediment samples, especially in Stations F5, F6, F13, B7, B8 and J. In samples F13 and B7, especially, clay minerals $1: 1$ and $\mathrm{Fe}, \mathrm{Al}$, and $\mathrm{Ti}$ oxides were detected in the $\mathrm{X}$-ray results that can explain the highest sorption capacity of the sediment on the mentioned stations.

Higher results of electrical conductivity can be due to a higher concentration of divalent cations in sediments, probably coming from overestimated fertilization in the areas of cultivation in both watersheds, as this is a common practice in areas of intensive agriculture. Less soluble salts, in this case, $\mathrm{Ca}^{2+}$ and $\mathrm{Mg}^{2+}$, evidenced by total alkalinity, and large 
amounts of total phosphorus and heavy metals (deriving from pesticides, mainly) may be adsorbed in iron oxides $\left(\mathrm{Fe}^{3+}\right)$, which when reaching the water bodies, are reduced $\left(\mathrm{Fe}^{2+}\right)$ releasing these pollutants ions. So, in the areas of slopes and hill tops, adsorbed ions remain neutralized and stable, but when they reach the water channels, they are released, and may pollute the aquatic environment.

Studies by Barreto et al. (2007) indicate that sediments are the final destination of trace metals. When compared with other environmental compartments (water and air), they constitute compartment of highest concentration of metals. According to the authors, one of the important factors controlling the adsorption and retention of metals in sediment is the particle size, it being recognized that most of the heavy metals are bound to the fine fraction of sediments $(<0.002 \mathrm{~mm})$, mainly due to higher surface area and humic substances content. Therefore, there is an inverse correlation between the particle size and concentration of metals in sediment.

Even in the middle and lower stretches of both watersheds, with good agricultural potential, excessive soil disturbance and insufficient reposition of organic matter favor physical deterioration, and also causes increased runoff and contamination of surface water with sediment, nutrients, animal waste and pesticides that are adsorbed by clays (Merten and Minella, 2002).

Lemes et al. (2003), assessing sediments of water supply stations from the Rivers Pardo and Mogi-Guaçu (Northeast of São Paulo State), found higher values of iron and manganese in areas with lower vegetative cover (compared with other areas with higher vegetative cover) indicating metal inputs from rocks where the soil degradation was intense, allowing the release of these minerals. They also observed higher phosphorous concentrations in stations near urban areas. Comparing two preserved headwaters and two under the influence of sugar cane crops, Donadio et al. (2005) also found significant differences in temperature, color, turbidity, alkalinity and total nitrogen, with higher values in those with vegetation exploited by agriculture.

Regarding the organic matter content, Stations B8, F13 and J have higher percentages probably related to the influence of the Marimbondo Reservoir. Due to longer residence time, there is the accumulation of fine sediment that contains a higher percentage of organic matter compared to those stations located in lotic stretches of the two watersheds. On the other hand, the higher percentages of organic matter in Stations F7 and B7, are caused by underground sewage discharges in the urban perimeter of Frutal Stream and the advanced state of silting due to complete suppression of riparian vegetation, respectively. These are among the most impacted in the two watersheds.

Considering the rainy season, the Bebedouro Stream has more organic matter than the Frutal Stream. The increased production of biomass, the entrance of allochthonous material and the better conservation status of riparian vegetation and soils probably explains this.

As with the clays, organic matter has a decisive role in the ion exchange of soil, adsorbing several nutrients and pollutants, coming from application of inputs in agricultural areas. Furthermore, it is important for water retention in the soil and for its structure (formation of organo-mineral complexes), besides being a source of nutrients for microorganisms.

Once sand was the dominant fraction in the sediment (due, mainly, to the medium texture of Rhodic Ferralsols formed by weathering from sandstones of Vale do Rio do Peixe Formation); it is possible to infer that agricultural activity is the potential cause of accelerated erosion and silting of the two watersheds.

If the erosion and silting processes continue at this rate in watershed of the Frutal Stream, the estimated scenario with its respective population projection and hydric demands suggests that in two decades the water catchment will not be enough to supply the city, according to a 
report from the Water Supply Company of Minas Gerais State - COPASA (Sepúlveda, 2009).

\section{CONCLUSIONS}

Agricultural activity can be considered the main cause of accelerated erosion and silting of the two watersheds. Quartz is the predominant mineral in studied sediments due to the fact that the soils of the region are formed largely from sandstones, indicating, consequently, little nutritional reserves in the materials studied. Outcrop/weathering of basalts from Serra Geral Formation, which is stratigraphically below the sandstones of Vale do Rio do Peixe Formation, contributes to the occurrence of clay minerals found in X-ray diffraction (XRD).

The Bebedouro Stream shows a better conservation status once it is completely inserted in a rural area, with larger riparian vegetation and without urbanization as is the case of the Frutal Watershed. Principal component analysis revealed that water quality variables showed high correlation values with the silt/clay fraction and/or organic matter in the sediment samples. Physical deterioration of soils causes increased runoff and contamination of surface water with sediment, nutrients, animal waste and pesticides that are adsorbed by clays.

\section{ACKNOWLEDGEMENTS}

To the Project TCT 17049/2011 - SECTES/FAPEMIG/HIDROEX - Diagnosis of Watersheds for Sustainability that financed this research and PIBIC/UEMG/FAPEMIG for the undergraduate grants (Process number 07/2011 and 06/2012).

\section{REFERENCES}

ASSOCIAÇÃO BRASILEIRA DE NORMAS TÉCNICAS - ABNT. NBR 6502: rochas e solos. Rio de Janeiro, 1995.

AMERICAN PUBLIC HEALTH ASSOCIATION - APHA; AMERICAN WATER WORKS ASSOCIATION - AWWA, WATER ENVIRONMENT FEDERATION - WEF. Standard Methods for examination of water and wastewater. 22nd ed. Washington, DC, 2012. 1360 p.

ALMEIDA, B. G.; DONAGEMMA, G. K.; RUIZ, H. A.; BRAIDA, J. A.; VIANA, J. H. M.; REICHERT, J. M. M. et al. Padronização de métodos para análise granulométrica no brasil. Comunicado Técnico ${ }^{\circ}{ }^{6}$ 66. Rio de Janeiro: Embrapa, 2012. 11 p.

BARRETO, M. S.; ALVES, J. P. H.; PASSOS, E. A.; GARCIA, C. A. B. Distribuição de metais pesados na fração fina $(<63 \mu \mathrm{m})$ dos sedimentos superficiais da sub-bacia hidrográfica do rio Poxim - SE. São Paulo: Sociedade Brasileira de Química, 2007. $175 \mathrm{p}$.

BICUDO, D. C.; BICUDO, C. E. M. Amostragem em limnologia. São Carlos: Rima, 2004. $372 \mathrm{p}$.

BISH, D. L.; POST, J. E. Modern powder diffraction. Reviews in Mineralogy, 20. Washington, DC: Mineralogical Society of America, 1989. 369 p.

CARDOSO, A. A. G. Diagnóstico e Implantação de Práticas Conservacionistas na SubBacia do Córrego Frutal, Frutal (MG). 2008. 42 f. Monografia (Especialização em Gestão e Manejo Ambiental em Sistemas Agrícolas) - Universidade Federal de Lavras, Lavras, 2008. 
CONSELHO NACIONAL DO MEIO AMBIENTE - CONAMA (Brasil). Resolução $n^{\circ} 357$, de 17 de março de 2005. Classificação dos corpos de água e diretrizes ambientais para o seu enquadramento, bem como estabelece as condições e padrões de lançamento de efluentes. Diário Oficial [da] União, Brasília, v. 53, p. 58-63, 18 mar. 2005.

COMPANHIA DE PESQUISA DE RECURSOS MINERAIS - CPRM; SERVIÇO GEOLÓGICO E MINERALÓGICO DO BRASIL - SGMB. Mapa geológico do estado de Minas Gerais. Brasília, DF, 2003. Escala de 1:1.000.000.

CUNHA, N. R. S.; LIMA, J. E.; GOMES, M. F. M.; BRAGA, M. J. A intensidade da exploração agropecuária como indicador da degradação ambiental na região dos Cerrados, Brasil. Economia e Sociologia Rural, v. 46, n. 2, p. 291-323, 2008. http://dx.doi.org/10.1590/S0103-20032008000200002

DONADIO, N. M. M.; GALBIATTI, J.A.; PAULA, R.C. 2005. Qualidade da água de nascentes com diferentes usos do solo na bacia hidrográfica do Córrego Rico, São Paulo, Brasil. Engenharia Agrícola, v. 25, n. 1, p. 115-125, 2005. http://dx.doi.org/10.1590/S0100-69162005000100013

ESTEVES, F. A. Fundamentos de limnologia. 3. ed. Rio de Janeiro: Interciência, 2011. 826 p.

FERREIRA, D. J. F. Dinâmica de transporte de sedimento em dois sistemas lóticos da cidade de Frutal - MG. 2005. 31 f. Monografia (Geografia) - Universidade do Estado de Minas Gerais, Frutal, 2005.

INSTITUTO BRASILEIRO DE GEOGRAFIA E ESTATÍSTICA - IBGE. Cidades. 2014. Available in: http://www.cidades.ibge.gov.br/xtras/home.php. Access in: May 2016.

KÄMPF, N.; MARQUES, J. J.; CURI, N. Mineralogia de solos brasileiros. In: KER, J. C.; CURI, N.; SCHAEFER, C. E.; TORRADO, P. V. Pedologia: fundamentos. Viçosa: SBCS, 2012. p. 81-146.

KLINK, C. A.; MACHADO, R. B. Conservation of the Brazilian Cerrado. Conservation Biology, v. 19, p. 707-713, 2005. http://dx.doi.org/10.1111/j.1523-1739.2005.00702.x

LAL, R. Soil degradation by erosion. Land Degradation and Development, v. 12, n. 6, p. 519-539, 2001.

LEMES, M. J. M; FIGUEIREDO-FILHO, P. M.; PIRES, M. A. F. Influência da mineralogia dos sedimentos das bacias hidrográficas dos rios mogi-guaçu e pardo na composição química das águas de abastecimento público. Química Nova, v. 26, n. 1, p. 13-20, 2003. http://dx.doi.org/10.1590/S0100-40422003000100004

MENEZES, E. Mapa da área aproximada das bacias do ribeirão Frutal e Córrego Bebedouro. Frutal: Topogeo, 2011. Escala 1:30.000.

MERTEN, G. H.; MINELLA, J. P. Qualidade da água em bacias hidrográficas rurais: um desafio atual para a sobrevivência futura. Agroecologia e Desenvolvimento Rural Sustentável, v. 3, n. 4, p. 33-38, 2002.

MORGAN, R. P. C. Soil erosion and conservation. $3^{\text {rd }}$ ed. Hoboken: Wiley-Blackwell, 2005. 304p.

PAYNE, A. I. The ecology of tropical lakes and rivers. New York: John Wiley \& Sons, 2006. 
SANTOS, J. A. G. Poluição do solo e da água. In: ARAÚJO, Q. R. 500 anos de uso do solo no Brasil. Ilhéus: Editus, 2002. p. 239-246.

SANTOS, R. D.; LEMOS, R. C.; SANTOS, H. G.; KER, J. C.; ANJOS, L. H. C.; SHIMIZU, S. H. Manual de descrição e coleta de solo no campo. 5. ed. Viçosa: SBCS, 2013. 100 p.

SOUZA, A. N. Diagnóstico da situação do córrego Vertente Grande, município de Frutal, MG. 2009. 37 f. Monografia (Graduação em Geografia) - Universidade do Estado de Minas Gerais, Frutal, 2009.

SUGUIO, K. Introdução à sedimentologia. São Paulo: Edgard Blucher, 1973. 317p.

SEPÚLVEDA, W. O. Relatório de definição de fonte de produção. Frutal: COPASA, 2009. $14 \mathrm{p}$.

VARANDA, L. Avaliação do projeto CENEP - COPASA 2004 a 2006. Frutal: COPASA, 2007. $11 \mathrm{p}$. 